\title{
PENGARUH KEPEMIMPINAN KEPALA SEKOLAH DAN MOTIVASI KERJA TERHADAP KINERJA GURU DI SMP SE-KECAMATAN BANJAR BARU KABUPATEN TULANG BAWANG
}

Nanang Avandi ${ }^{1}$, Sudirman Aminin ${ }^{2 *}$, Nyoto Suseno ${ }^{3}$

${ }^{1,2,3}$ Universitas Muhammadiyah Metro, Metro, Indonesia dan Indonesia

E-mail:

avandinanang@gmail.com ${ }^{1}$

Sudirman.am57@gmail.com ${ }^{2}$

nyotoseno@gmail.com ${ }^{3}$

\begin{abstract}
Abstrak
Tujuan penelitian ini untuk mengetahui: 1) Mendeskripsikan seberapa besar pengaruh kepemimpinan kepala sekolah terhadap kinerja guru di SMP Se-Kecamatan Banjar Baru Kabupaten Tulang Bawang, 2) Mendeskripsikan seberapa besar pengaruh motivasi kerja terhadap kinerja gurudi SMP Se-Kecamatan Banjar Baru Kabupaten Tulang Bawang, 3) Mendeskripsikan seberapa besar pengaruh kepemimpinan kepala sekolah dan motivasi kerja terhadap kinerja guru SMP Se-Kecamatan Banjar Baru Kabupaten Tulang Bawang, 4) Mendeskripsikan pelaksanaan penelitian tentang pengaruh kepemimpinan kepala sekolah dan motivasi kerja guru terhadap kinerja guru di SMP Se-Kecamatan Banjar Baru Kabupaten Tulang Bawang. Penelitian ini rancangannya adalah "penelitian kuantitatif melalui pendekatan survei dengan uji pengaruh menggunakan teknik respondend cluster random sampling. Instrumen yang digunakan berupa angket. Metode pengumpulan data menggunakan metode angket sebagai metode utama, yang dibantu dengan metode wawancara dan observasi sebagai metode pendukung. Hasil penelitian menunjukkan bahwa terdapat pengaruh kepemimpinan kepala sekolah $\left(\mathrm{X}_{1}\right)$ terhadap kinerja guru (Y) dengan besarnya kontribusi sebesar 0,277 atau $27,7 \%$, terdapat pengaruh motivasi kerja $\left(\mathrm{X}_{2}\right)$ terhadap kinerja guru (Y) dengan besarnya kontribusi sebesar 0,363 atau 36,3\%, dan terdapat pengaruh secara bersama-sama antara kepemimpinan kepala sekolah $\left(\mathrm{X}_{1}\right)$ dan motivasi kerja guru $\left(\mathrm{X}_{2}\right)$ terhadap kinerja guru( $\left.\mathrm{Y}\right)$ dengan besarnya kontribusi sebesar 0,384 atau $38,4 \%$.
\end{abstract}

Kata Kunci: Kepemimpinan, Kinerja, Motivasi

\begin{abstract}
The purpose of this study was to determine: 1) Describe how much influence the leadership of school principals on the performance of teachers in SMPs in the District of Banjar Baru, Tulang Bawang District, 2) Describe how much influence the motivation of work on the performance of teachers of SMPs in the District of Banjar Baru, Tulang Bawang Regency, 3) Describe how much influence the leadership of school principals and work motivation on the performance of junior high school teachers in the Banjar Baru Subdistrict Tulang Bawang Regency, 4) Describe conducting research on the influence of school principal leadership and teacher work motivation on teacher performance in SMPs in the Banjar Baru Subdistrict, Tulang Bawang Regency. The results showed that there was an influence of school leadership (XI) on teacher performance $(Y)$ with a contribution of 0.277 or $27.7 \%$, there was an influence of work motivation (X2) on teacher performance $(Y)$ with a contribution amount of 0.363 or $36,3 \%$, and there is a joint effect between the leadership of the principal (X1) and teacher work motivation (X2) on teacher performance (Y) with a contribution of 0.384 or $38.4 \%$.
\end{abstract}

Keywords: Leadership, Motivation, Performance. 


\section{PENDAHULUAN}

Pendidikan adalah suatu hal yang sangat penting bagi kehidupan manusia. Karena pendidikan diyakini masyarakat dan pemerintah dapat meningkatkan kualitas Sumber Daya Manusia (SDM) dan segala potensi serta bakat yang dimiliki untuk dapat ditumbuh-kembangkan. Pendidikan sendiri diharapkan dapat bermanfaat bagi diri sendiri maupun kepentingan orang banyak. Oleh karena itu Pendidikan sangatlah penting untuk suatu bangsa sebagai dasar pembangunan bangsa, karena tanpa adanya pendidikan bangsa ini akan menjadi bangsa yang bodoh. UUD 1945 Tahun 2003 menjelaskan bahwa setiap warga Negara Indonesia berhak mendapat pendidikan.

Kemampuan guru sangatlah penting dalam proses pembelajaran dan hasil belajar dari peserta didik. Proses pembelajaran dan hasil belajar dari peserta didik tidak hanya ditentukan oleh sekolah dan kurikulum apa yang digunakan, akan tetapi sebagian besar ditentukan oleh kompetensi dari guru yang mengajar dan membimbing mereka. Dengan demikian, guru dituntut untuk memiliki kemampuan atau kompeteni sehingga ia mampu mengajar dan membimbing peserta didik untuk tumbuh dan berkembang sesuai yang diharapkan. Oleh karena itu kinerja seorang guru perlu ditingkatkan dengan cara memberi pembinaan dan pengembangan profesi guru yang bertujuan meningkatkan kinerja guru yang optimal, dan hal ini harus dilakukan secara terus menerus agar mampu menciptakan kinerja sesuai yang diinginkan. Semakin sering kegiatan diberikan maka semakin dekat guru pada pencapaian prestasi dalam hal menjalankan tugasnya dan harapan kinerja guru yang profesional dapat tercapai.

Dalam rangka membentuk kinerja guru yang optimal terdapat dua faktor yang dapat mempengaruhinya agar lebih baik lagi, yaitu faktor internal (dari diri sendiri) dan faktor eksternal (dari luar diri) . Menurut Ahmad (2017) Faktor pendukung kinerja guru terdiri dari faktor internal, yakni 1) kecerdasan, 2) keterampilan dan kecakapan, 3) bakat, 4) Kemampuan dan minat, 5) Motif, 6) Kesehatan, 7) Kepribadian, dan 8) Cita-Cita dan tujuan dalam bekerja, sedangkan faktor eksternal yakni, 1) lingkungan keluarga, 2) lingkungan kerja, 3) komunikasi dengan kepala sekolah, 4) sarana dan prasarana, 5) kegiatan guru di kelas, dan 6) kegiatan guru di sekolah.

Terlihat dari beberapa pendapat di atas untuk mendapatkan kinerja guru yang optimal maka perlu adanya motivasi kerja dari diri guru itu sendiri serta adanya koordinasi yang baik dengan warga sekolah khususnya yaitu kepala sekolah. Faktor kepemimpinan kepala sekolah dan motivasi kerja dari guru itu sendirilah yang dipandang memiliki peran yang penting untuk peningkatan kinerja dari guru tersebut. Kepemimpinan kepala sekolah adalah kunci dalam mewujudkan sekolah yang berhasil. Keberhasilan sekolahpun tidak lepas dari peran kepala sekolah dalam menjalankan fungsi kepemimpinannya. Dikatakan berhasil apabila kepala sekolah tersebut dapat memahami faktor-faktor yang menjadikannya mampu dan berhasil dalam memimpin sekolah sehingga memudahkan baginya untuk menentukan langkah sebagai upaya mewujudkan keberhasilan tersebut. Menurut Mulyasa (2013: 47-45) mengungkapkan 11 ciri kepemimpinan kepala sekolah yang ideal yaitu: (1) fokus pada kelompok, (2) melimpahkan wewenang, (3) merangsang kreativitas, (4) memberi semangat dan motivasi, (5) memikirkan program penyertaan bersama, (6) kreatif dan proaktif, (7) memperhatikan sumber daya manusia, (8) membicarakan persaingan, (9) membangun karakter, (10) kepemimpinan yang tersebar, dan (11) bekerja sama dengan masyarakat.

Kepemimpinan kepala sekolah sangat berpengaruh dalam meningkatkan kinerja guru, sehingga mereka semangat dalam melaksanakan tugas dan tanggung jawab dengan penuh kedisiplinan dan pengabdian yang tinggi. Karena perilaku kepala sekolah yang baik artinya kepala sekolah yang dapat mempengaruhi, memotivasi, menggerakan, mengarahkan, membimbing seluruh warga sekolah dalam mencapai visi misi sekolah itu sendiri. Kepemimpinan kepala sekolah merupakan faktor yang menentukan mutu sekolah itu sendiri, karena pada dasarnya perilaku kepala sekolah yang tepat akan berperngaruh dalam pengambilan keputusan, atau mempengaruhi guru untuk melakukan pekerja yang lebih baik lagi. Oleh karena itu kepala sekolah harus mampu mempengaruhi orang lain baik individu maupun kelompok. Kepala sekolah sendiri 
yang dapat memegang kendali dalam sekolah sehingga guru dalam mengerjakan tugasnya dipengaruhi oleh dorongan dalam diri individu, dorongan yang dimaksud disini adalah motivasi.

Tidak hanya faktor kepemimpinan kepala sekolah saja yang mempengaruhi kinerja dari seorang guru, melainkan ada faktor lain yaitu motivasi kerja. Menurut Hasibuan (2010) menjelaskan bahwa motivasi adalah pemberian daya gerak yang menciptakan kegairahan kerja seseorang, agar mereka mau bekerja sama, bekerja efektif dan terintegrasi dengan segala daya upayanya untuk mencapai kepuasan. Sehingga guru yang memiliki motivasi tinggi tercermin dari sikap dan perilaku guru yang mau bekerja keras, cenderung bertindak, mendayagunakan segenap kemampuan, pikiran, keterampilan untuk mewujudkan tujuan.

Hal-hal seperti inilah yang dapat mempengaruhi kinerja guru tidak maksimal. Oleh karena itu langkah yang dilakukan kepala sekolah dalam meningkatkan kinerja guru di SMP seKecamatan Banjar Baru Kabupaten Tulang Bawang antara lain dengan memaksimalkan peran kepemimpinannya serta memberikan penguatan motivasi kepada guru-guru. Dariu raian latar belakang tersebut kepemimpinan kepala sekolah, motivasi kerja dan kinerja guru sangat menarik untuk diteliti. Dengan demikian dalam rangka berpartisipasi meningkatkan mutu pendidikan di SMP Se-kecamatan Banjar Baru Kabupaten Tulang Bawang, khususnya meningkatkan kinerja guru SMP Se-Kecamatan Banjar Baru Kabupaten Tulang Bawang melalui kepemimpinan kepala sekolah dan motivasi kerja guru maka penulis tertarik menjawab pertanyaan yang perlu diteliti tentang Pengaruh Kepemimpinan Kepala Sekolah dan Motivasi Kerja Terhadap Kinerja Guru. Adapun tujuan penelitian ini adalah: 1) Mendeskripsikan seberapa besar pengaruh kepemimpinan kepala sekolah terhadap kinerja guru di SMP Se-Kecamatan Banjar Baru Kabupaten Tulang Bawang. 2) Mendeskripsikan seberapa besar pengaruh motivasi kerja terhadap kinerja gurudi SMP Se- Kecamatan Banjar Baru Kabupaten Tulang Bawang. 3) Mendeskripsikan seberapa besar pengaruh kepemimpinan kepala sekolah dan motivasi kerja terhadap kinerja guru SMP SeKecamatan Banjar Baru Kabupaten Tulang Bawang. 4) Mendeskripsikan bagaimana pelaksanaan kepemimpinan kepala sekolah, motivasi kerja guru dan kinerja guru di SMP Se-Kecamatan Banjar Baru Kabupaten Tulang Bawang.

\section{METODE PENELITIAN}

Penelitian ini adalah bentuk dari jenis penelitian kuantitatif yaitu penelitian yang awal di mulainya menggunakan dengan berpikir deduktif untuk menurunkan hipotesis, kemudian melakukan pengujian di lapangan, kesimpulan atau hipotesis tersebut ditarik berdasarkan data empirik. Populasi dalam penelitian ini adalah guru yang ada di SMP Se- Kecamatan Banjar Baru Kabupaten Tulang Bawang yang berjumlah 102 orang. Berdasarkan hasil pengumpulan data yang telas dilakukan, sampel dari penelitian ini adalah guru yang ada di SMP SeKecamatan Banjar Baru Kabupaten Tulang Bawang yang berjumlah 50 orang dengan menggunakan teknik respondend cluster random sampling dan instrumen pengumpulan data berupa metode angket sebagai metode utama, yang dibantu dengan metode wawancara dan observasi sebagai metode pendukung. Sedangkan teknik analisis datanyanya menggunakan teknik analsis deskriptif, uji prasyarat dan uji hipotesis.

\section{HASIL DAN PEMBAHASAN}

Hasil pengujian prasyarat analisis menggunakan bantuan program SPSS menyimpulkan bahwa data-data yang diperoleh dari lapangan berasal dari populasi yang berdistribusi normal. Kemudian berdasarkan hasil uji homogenitas varians diperoleh data mempunyai varians yang sama. Setelah pengujian prasyarat terpenuhi maka dilakukan pengujian hipotesis dengan hasil sebagai berikut: 


\section{1) Pengaruh Kepemimpinan Kepala Sekolah $\left(X_{1}\right)$ terhadap Kinerja Guru (Y)}

Tabel 1. Korelasi antara $\mathrm{X}_{1}$ dan $\mathrm{Y}$

\begin{tabular}{|c|c|c|c|c|c|}
\hline \multicolumn{6}{|c|}{ Model Summary $^{\text {b }}$} \\
\hline Model & $\mathbf{R}$ & R Square & $\begin{array}{c}\text { Adjusted R } \\
\text { Square }\end{array}$ & $\begin{array}{c}\text { Std. Error of the } \\
\text { Estimate }\end{array}$ & Durbin-Watson \\
\hline 1 & $.526^{\mathrm{a}}$ & .277 & .262 & 8.124 & 1.653 \\
\hline \multicolumn{6}{|c|}{$\begin{array}{l}\text { a. Predictors: (Constant), Kepemimpinan Kepala Sekolah } \\
\text { b. Dependent Variable: Kinerja }\end{array}$} \\
\hline
\end{tabular}

Sumber: Diolah Dari Hasil Penelitian, Menggunakan Aplikasi SPSS Versi 17

Hasil perhitungan pada tabel 1 menunjukan bahwa koefisien korelasi anatara kepemimpinan kepala sekolah dan kinerja guru adalah positif. Hal ini dapat dilihat pada koefisien korelasinya sebesar 0,526. Berdasarkan hasil perhitungan dapat dijelaskan bahwa kepemimpinan kepala sekolah berkorelasi dengan kinerja guru dengan membentuk hubungan yang positif dengan koefisien determinasi 0,277. Berikutnya untuk mengetahui bentuk hubungan kepemimpinan kepala sekolah $\left(\mathrm{X}_{1}\right)$ dengan kinerja guru $\quad(\mathrm{Y})$, apakah hubungan itu berpengaruh atau tidak maka dapat dilihat pada tabel 2 berikut:

Tabel 2. Hasil Analisis Regresi Sederhana $X_{1}$ terhadap Y

\begin{tabular}{|c|c|c|c|c|c|c|}
\hline \multicolumn{7}{|c|}{ Coefficients $^{\mathrm{a}}$} \\
\hline & \multirow{2}{*}{ Model } & \multicolumn{2}{|c|}{$\begin{array}{c}\text { Unstandardized } \\
\text { Coefficients } \\
\end{array}$} & \multirow{2}{*}{$\begin{array}{r}\begin{array}{r}\text { Standardized } \\
\text { Coefficients }\end{array} \\
\text { Beta }\end{array}$} & \multirow[t]{2}{*}{$\mathbf{t}$} & \multirow[t]{2}{*}{ Sig. } \\
\hline & & B & $\begin{array}{l}\text { Std. } \\
\text { Error }\end{array}$ & & & \\
\hline \multirow[b]{2}{*}{1} & (Constant) & 53.557 & 10.699 & & 5.006 & .000 \\
\hline & $\begin{array}{l}\text { Kepemimpinan } \\
\text { Kepala Sekolah }\end{array}$ & .494 & .115 & .526 & 4.287 & .000 \\
\hline Depe & ble: Kinerja Guru & & & & & \\
\hline
\end{tabular}

Sumber: Diolah Dari Hasil Penelitian, Menggunakan Aplikasi SPSS Versi 17

Hasil analisis pada tabel 2 diperoleh persamaan regresi sebagai berikut: Daya prediksi model regresi yang ditemukan di atas ditentukan oleh koefisien arah sebesar 0,494. Ini menunjukan bahwa setiap peningkatan kepemimpinan kepala sekolah sebesar 1 skala akan berkontribusi terhadapa penigkatan kinerja guru sebesar 0,494 skala. Sementara nilai kinerja guru sudah ada sebesar 53,557 skala tanpa adanya kepemimpinan kepala sekolah. Sebagai contoh seorang guru menilai kepemimpinan kepala sekolah sebesar 100 skala, maka kinerja guru selanjutnya dapat diprediksi sebesar $100 \times 0,494+53,557=102,957$. Ternyata dengan meningkatnya kepemimpinan kepala sekolah maka kinerja guru ikut meningkat.

Hasil analisis juga menunjukan variabel kepemimpinan kepala sekolah $\left(\mathrm{X}_{1}\right)$ memiliki $\mathrm{t}_{\text {hitung }}=4,287>\mathrm{t}_{\text {tabel }}=0,279$ dengan signifikansi $0.000<0.05$ maka H0 ditolak dan Ha diterima berarti kepemimpinan kepala sekolah memiliki pengaruh positif dan signifikan terhadap kinerja guru. Analisis di atas memperlihatkan bahwa hipotesis penelitian yang menyatakan kepemimpinan kepala sekolah berpengaruh terhadap kinerja guru dapat diterima dan telah diuji kebenarannya secara empiris pada taraf kepercayaan 95\%. Selanjutnya, dapat diinterpretasikan bahwa faktor kepemimpinan kepala sekolah berpengaruh signifikan terhadapa kinerja guru. pengaruh kepemimpinan kepala sekolah terhadap kinerja guru SMP Se-kecamatan Banjar Baru, Kabupaten Tulang Bawang sebesar 0.277 atau 27,7\%.0.277 atau 27,7\%. sisanya $72,3 \% \%$ kinerja guru dipengaruhi oleh variabel lain diluar persamaan regresi ini atau variabel yang tidak diteliti. 


\section{2) Pengaruh Motivasi Kerja Terhadap Kinerja Guru}

Untuk mengetahui pengaruh motivasi kerja guru terhadap kinerja.

Tabel 3. Korelasi antara $\mathrm{X}_{2}$ dan $\mathrm{Y}$ guru dilakukan analisis korelasi dan regresi Sederhana.

\begin{tabular}{lccccc}
\hline \multicolumn{6}{c}{ Model Summary $^{\mathbf{b}}$} \\
\hline Model & R & R Square & $\begin{array}{c}\text { Adjusted R } \\
\text { Square }\end{array}$ & $\begin{array}{c}\text { Std. Error of } \\
\text { the Estimate }\end{array}$ & Durbin-Watson \\
\hline 1 & $.602^{\mathrm{a}}$ & .363 & .349 & 7.628 & 1.409 \\
\hline $\begin{array}{l}\text { a. Predictors: (Constant), Motivasi Kerja } \\
\text { b. Dependent Variable: Kinerja }\end{array}$ & & & \\
\hline
\end{tabular}

\section{Sumber: Diolah Dari Hasil Penelitian, Menggunakan Aplikasi SPSS Versi 17}

Hasil perhitungan pada tabel 3 menunjukan bahwa koefisien korelasi anatara motivasi kerja guru dan kinerja guru adalah positif. Hal ini dapat dilihat pada koefisien korelasinya sebesar 0,602. Berdasarkan hasil perhitungan dapat dijelaskan bahwa motivasi kerja guru berkorelasi dengan kinerja guru dengan membentuk hubungan yang positif dengan koefisien determinasi 0,363. Berikutnya untuk mengetahui bentuk hubungan Motivasi Kerja (X2) dengan kinerja guru (Y), apakah hubungan itu berpengaruh atau tidak maka dapat dilihat pada tabel 4 berikut:

Tabel 4. Hasil Analisis Regresi Sederhana $\mathrm{X}_{2}$ terhadap Y

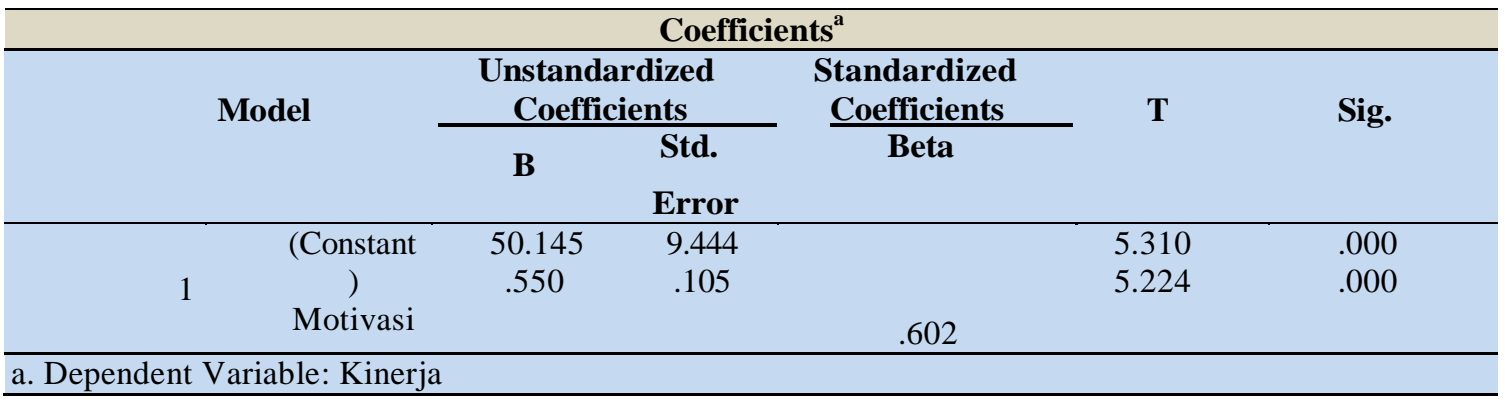

Sumber: Diolah Dari Hasil Penelitian, Menggunakan Aplikasi SPSS Versi 17

Hasil analisis pada tabel 4 diperoleh persamaan regresi sebagai berikut: daya prediksi model regresi yang ditemukan di atas ditentukan oleh koefisien arah sebesar 0,550. Ini menunjukan bahwa setiap peningkatan motivasi kerja guru sebesar 1 skala akan berkontribusi terhadapa penigkatan kinerja guru sebesar 0,550 skala. Sementara nilai kinerja guru sudah ada sebesar 50,145 skala tanpa adanya motivasi kerja guru. Sebagai contoh seorang guru menilai motivasi kerja guru sebesar 100 skala, maka kinerja guru selanjutnya dapat diprediksi sebesar 100 x 0,550+ $50,145=105,145$. Ternyata dengan meningkatnya motivasi kerja guru maka kinerja guru ikut meningkat. Hasil analisis juga menunjukan variabel kepemimpinan kepala sekolah $\left(\mathrm{X}_{1}\right)$ memiliki $\mathrm{t}_{\text {hitung }}=5,224>\mathrm{t}_{\text {tabel }}=0,279$ dengan signifikansi $0.000<0.05$ maka $\mathrm{H} 0$ ditolak dan Ha diterima berarti motivasi kerja guru memiliki pengaruh positif dan signifikan terhadap kinerja guru. Analisis di atas memperlihatkan bahwa hipotesis penelitian yang menyatakan motivasi kerja guru berpengaruh terhadap kinerja guru dapat diterima dan telah diuji kebenarannya secara empiris pada taraf kepercayaan $95 \%$.

Selanjutnya, dapat diinterpretasikan bahwa faktor motivasi kerja guru berpengaruh signifikan terhadapa kinerja guru. pengaruh motivasi kerja guru terhadap kinerja guru SMP Sekecamatan Banjar Baru, Kabupaten Tulang Bawang sebesar 0.363 atau 36,3\%, sisanya 62,7\%\% kinerja guru dipengaruhi oleh variabel lain diluar persamaan regresi ini atau variabel yang tidak diteliti.

\section{3) Pengaruh Kepemimpinan Kepala Sekolah $\left(X_{1}\right)$ dan Perilaku Kewarganegaraan Organisasi $\left(\mathrm{X}_{2}\right)$ terhadap Kinerja Guru (Y)}


Selanjutnya hasil perhitungan data mengenai kepemimpinan kepala sekolah dan motivasi kerja guru secara bersama-sama berpengaruh terhadap kinerja guru, analisis pengujian hipotesisnya menggunakan teknik korelai regresi ganda. Hasil analisis korelasi dapat dilihat pada tabel 5, berikut ini:

Tabel 5. Korelasi Ganda antara $X_{1}, X_{2}$ dan $Y$

\begin{tabular}{|c|c|c|c|c|}
\hline \multicolumn{5}{|c|}{ Model Summary $^{b}$} \\
\hline Model & $\mathbf{R}$ & R Square $\begin{array}{r}\text { Adjusted R } \\
\text { Square }\end{array}$ & $\begin{array}{l}\text { Std. Error of } \\
\text { the Estimate }\end{array}$ & Durbin-Watson \\
\hline 1 & $.620^{\mathrm{a}}$ & .384 & 7.575 & 1.509 \\
\hline \multicolumn{5}{|c|}{ a. Predictors: (Constant), Motivasi Kerja , Kepemimpinan Kepala Sekolah } \\
\hline \multicolumn{5}{|c|}{ b. Dependent Variable: Kinerja Guru } \\
\hline
\end{tabular}

Sumber: Diolah Dari Hasil Penelitian, Menggunakan Aplikasi SPSS Versi 17

Hasil perhitungan pada tabel 25 di atas menunjukan bahwa koefisien korelasi ganda sebesar 0,620 dan koefisien determinasi sebesar 0,384. Berdasarkan hasil perhitungan dapat dijelaskan bahwa terdapat korelasi signifikan antara kepemimpinan kepala sekolah dan motivasi kerja guru secara bersama- sama dengan kinerja guru. Berikutnya untuk mengetahui bentuk hubungan kepemimpinan kepala sekolah $\left(\mathrm{X}_{1}\right)$ dan motivasi kerja Tabel 6. Hasil Uji $F \mathrm{X}_{1}$ dan $\mathrm{X}_{2}$ terhadap $\mathrm{Y}$ $\left(\mathrm{X}_{2}\right)$ secara bersama-sama dengan kinerja guru $(\mathrm{Y})$, dapat dilihat pada tabel 6 berikut:

Tabel 6. Uji $F \mathrm{X}_{1}$ dan $\mathrm{X}_{2}$ terhadap $\mathrm{Y}\left(\mathrm{X}_{2}\right)$ secara bersama-sama dengan kinerja guru ( $\left.\mathrm{Y}\right)$

\begin{tabular}{|c|c|c|c|c|c|c|}
\hline \multicolumn{7}{|c|}{ ANOVA $^{0}$} \\
\hline & Model & $\begin{array}{l}\text { Sum of } \\
\text { Squares }\end{array}$ & df & $\begin{array}{c}\text { Mean } \\
\text { Square }\end{array}$ & $\mathbf{F}$ & Sig. \\
\hline \multirow{3}{*}{1} & Regression & 1.683 .917 & 2 & 841.958 & 14.674 & $.000^{\mathrm{a}}$ \\
\hline & Residual & 2.696 .803 & 47 & 57.379 & & \\
\hline & Total & 4.380 .720 & 49 & & & \\
\hline \multicolumn{7}{|c|}{ a. Predictors: (Constant), Motivasi Kerja, Kepemimpinan Kepala Sekolah } \\
\hline b. D & dent Variable & lerja Guru & & & & \\
\hline
\end{tabular}

Sumber: Diolah Dari Hasil Penelitian, Menggunakan Aplikasi SPSS Versi 17

Tabel 6 menunjukkan nilai $\mathrm{F}_{\text {hitung }}$ sebesar 14,647> $\mathrm{F}_{\text {tabel }} 3,19$ sementara tingkat signifikansi $0,000<0,05$ maka kedua indikator tersebut menunjukan bahwa pengaruh kepemimpinan kepala sekolaha dan motivasi kerja secara bersama-sama adalah positif dan signifikan terhadap kinerja guru.Selanjutnya untuk menguji hubungan antara variabel kepemimpinan kepala sekolah $\left(\mathrm{X}_{1}\right)$ dan motivasi kerja $\left(\mathrm{X}_{2}\right)$ benar-benar berpengaruh terhadap variabel kinerja guru $(\mathrm{Y})$ secara terpisah atau parsial dilakukan dengan uji $\mathrm{T}$.

Tabel 7. Hasil Analisis Regresi Berganda $\mathrm{X}_{1}, \mathrm{X}_{2}$ terhadap $\mathrm{Y}$

\begin{tabular}{|c|c|c|c|c|c|c|}
\hline \multicolumn{7}{|c|}{ Coefficients $^{\mathrm{a}}$} \\
\hline & \multirow{2}{*}{ Model } & \multicolumn{2}{|c|}{$\begin{array}{l}\text { Unstandardized } \\
\text { Coefficients }\end{array}$} & \multirow{2}{*}{$\begin{array}{c}\text { Standardized } \\
\text { Coefficients } \\
\text { Beta }\end{array}$} & \multirow{2}{*}{$\mathrm{t}$} & \multirow{2}{*}{ Sig. } \\
\hline & & B & Std. Error & & & \\
\hline \multirow{3}{*}{1} & (Constant) & 34.730 & 10.224 & & 3.397 & .001 \\
\hline & $\begin{array}{l}\text { Kepemimpinan } \\
\text { Kepala Sekolah }\end{array}$ & . 367 & .110 & .392 & 3.345 & .002 \\
\hline & $\begin{array}{l}\text { Motivasi Kerja } \\
\text { Guru }\end{array}$ & .372 & .104 & .418 & 3.570 & .001 \\
\hline
\end{tabular}

Sumber: Diolah Dari Hasil Penelitian, Menggunakan Aplikasi SPSS Versi 17 
Pada tabel 7. Dapat dilihat bahwa variabel kepemimpinan kepala sekolah $\left(\mathrm{X}_{1}\right)$ memiliki $\mathrm{t}$ hitung 3,345>t tabel 0,279 dengan signifikansi 0,002 berarti kepemimpinan kepala sekolah memiliki pengaruh positif dan signifikan terhadap kinerja guru. variabel motivasi kerja $\left(\mathrm{X}_{2}\right)$ memiliki $\mathrm{t}_{\text {hitung }}$ $3,570>t$ tabel 0,279 dengan signifikansi 0,001 berarti motivasi kerja guru memiliki pengaruh positif dan signifikan terhadap kinerja guru.

Dari hasil perhitungan diperoleh persamaan regresi kepemimpinan kepala sekolah dan motivasi kerja guru secara bersama- sama terhadap kinerja guru dengan model regresinya Daya prediksimodel regresi yang ditemukan di atas ditentukan oleh koefisien arah $\mathrm{X}_{1}$ sebesar 0,367 dan koefisien arah $\mathrm{X}_{2}$ sebesar 0,372. Ini berarti bahwa setiap peningkatan kepemimpinan kepala sekolah sebesar 1 skala akan berkontribusi terhadap nilai kinerja guru sebesar 0,367 skala, dan peningkatan motivasi kerja guru sebesar 1 skala akan berkontribusi terhadap penambahan kinerja guru sebesar 0.372. sebelumnya nilai kinerja guru sudah ada sebesar konstanta yaitu 34,730 skala tanpa ada pengaruh dari kedua prediktor tersebut. Sebagai contoh seorang kepala sekolah diketahui skor penilaian untuk kepemimpinan dan skor motivasi kerja guru masing-masing sebesar 100 skala, maka nilai kinerja guru tersebut dapat diprediksi sebesar 100x0,367+100x0,372 $+34,730=108,6$. Dengan demikian, hipotesis yang menyatakan bahwa kepemimpinan kepala sekolah dan motivasi kerja guru bersama-sama berkontribusi terhadap kinerja guru dapat diterima dan telah teruji secara empiri pada taraf kepercayaan 95\%. Ini berati bahwa model regresi ganda yang ditemukan dapat digunakan unuk meramalkan kinerja guru-guru di SMP se-Kecamatan Banjar Baru Kabupaten Tulang Bawang, bila skor kepemimpinan kepala sekolah dan motivasi kerja guru diketahui. Besar kontribusinya adalah 0,384 atau 38,4\%. Artinya kinerja guru dapat dijelaskan oleh variasi kepemimpinan kepala sekolah dan motivasi kerja guru. sedangkan sisanya sebesar $61,6 \%$ dapat dijelaskan oleh faktor lain yang tidak termasuk dalam penelitian ini. Misalnya budaya organisasi, disiplin, insentif dan lain sebagaianya.

\section{KESIMPULAN DAN SARAN}

Berdasarkan hasil temuan empirik yang sudah diuraikan di atas, dapat disimpulkan bahwa kepemimpinan kepala sekolah mempunyai pengaruh positif dan signifikan terhadap kinerja guru. Pengaruh motivasi kerja guru terhadap kinerja guru adalah sebesar $27,7 \%$, sedangkan sisanya $72,3 \%$ kinerja guru dipengaruhi oleh variabel lain diluar persamaan regresi ini atau variabel yang tidak diteliti. Motivasi kerja mempunyai pengaruh positif dan signifikan terhadap kinerja guru. Pengaruh motivasi kerja guru terhadap kinerja guru adalah sebesar 36,3\%, sedangkan sisanya 63,7\% kinerja guru dipengaruhi oleh variabel lain diluar persamaan regresi ini atau variabel yang tidak diteliti. Kepemimpinan kepala sekolah dan motivasi kerja guru mempunyai pengaruh positif dan signifikan secara bersama-sama terhadap kinerja guru. Kepemimpinan kepala sekolah dan motivasi kerja guru secara bersama-sama berpengaruh terhadap kinerja guru sebesar 38,4\%, sedangkan sisanya $61,6 \%$ kinerja guru dipengaruhi oleh variabel lain diluar persamaan regresi ini atau variabel yang tidak diteliti.

\section{DAFTAR PUSTAKA}

Ahmad, La Ode Ismail. 2017. Konsep Penilaian Kinerja Guru dan Faktor yang Mempengaruhinya. Dalam Jurnal Idaarah, Halaman 133- 142.

Ali, Muhammad. Strategi Penelitian Pendidikan. Cet. II; Bandung Angkasa, 1993.

Arif, Saiful. "Implementasi Supervisi Klinis", Jurnal Tadris 3, no. 2 (2008): h. 168. 
Bandung: Remaja Rosdakarya

Fanan, M. Athoiful. "Peningkatan kompetensi guru sekolah dalam pembelajaran di kelas", Jurnal Manajemen Pendidikan Islam, 3, no. 2 (2016)

Hasibuan, Malayu. 2010. Manajemen Sumber Daya Manusia. Jakarta: PT Bumi Aksara.

Mulyasa, E. 2013. Menjadi Kepala Sekolah Profesional. Bandung: Remaja Rosdakarya. 